\title{
Board Diversity and Corporate Sustainability Practices: Evidence on Environmental, Social and Governance (ESG) Reporting
}

\author{
Aida Maria Ismail ${ }^{1} \&$ Izrul Haida Mohd Latiff ${ }^{2}$ \\ ${ }^{1}$ Faculty of Accountancy, Universiti Teknologi MARA, Malaysia \\ ${ }^{2}$ Compliance Division, MBSB Bank, Kuala Lumpur, Malaysia \\ Correspondence: Aida Maria Ismail, Faculty of Accountancy, Universiti Teknologi MARA, Malaysia.
}

Received: April 20, 2019

Accepted: May 7, 2019

Online Published: May 19, 2019

doi:10.5430/ijfr.v10n3p31

URL: https://doi.org/10.5430/ijfr.v10n3p31

\begin{abstract}
The emerging awareness on sustainability issues among Malaysian listed companies has increased the voluntary disclosure on environmental, social and governance (ESG) in the annual report. This study examines the relationship of board diversity on firm's sustainability practices. Board diversity characteristics in terms of gender, age, board composition, board capabilities and board reputation are examined as to their influence towards firm's sustainability practice. The data includes the ESG Scores of 38 listed companies in Malaysia for the period in 2010-2016 which was obtained from the Thomson Reuters Eikon ${ }^{\mathrm{TM}}$ Datastream. The result showed that board diversity traits such as age, board capabilities and board reputation are positively associated with firm's sustainability practices. In contrast, women director and independent directors are negatively related with firm sustainability practice. Result of this study helps to provide another viewpoint on the roles played by board members, particularly their diversity representations as the determinant for corporate sustainability practice.
\end{abstract}

Keywords: firm's sustainability practices, board diversity characteristics, environmental, social and governance (ESG) disclosure, stakeholder theory, resource-based view (RBV) theory

\section{Introduction}

The emerging concern among investor groups to integrate environmental, social and governance (ESG) factors in the investment decision-making have necessitate regulators to impose the requirement for sustainability disclosure in the annual report on public listed companies. The ESG issues that we have seen today were mainly derived from weak corporate governance of the board of directors and its management executives. According to Goldin, I. and Vogel, T. (2010), the adverse result from corporate failures and scandals were not only causing financial losses to the investors but it also caused systemic impact to the economy, environment and society at large. The over-exploitation of natural resources for commercial purpose had caused other sustainability problems. Irresponsible practices of large corporations which over-exploit the natural resources had damaged the environment and will eventually detriment their firm's value and reputation. In the case of British Petroleum (BP) for example, the company was hit by health and safety issues as a result of oil spill incident in the Gulf of Mexico. The catastrophe impact from the oil-spill incident had damaged the marine ecosystem and caused the local residents to lose their main source of income (British Petroleum., 2015).The aftermath effects from the unfortunate event were not only damaging the environment but had resulted to significant devaluation of its share price. The firm had to face major lawsuits and legal actions from the authority as a result of safety breaches (Cruden et al., 2016).

Aside from governance and environmental concerns as explained earlier, investors now a day's paid due regard to the ethical conduct of business when making investment decisions. For example, fair treatment of employees and basic human rights are among the criteria that the firms should give attention to while pursuing for commercial objectives (Renneboog et al., 2008 and Auer \& Schumacher, 2016). Any unfair treatment of labour force could have direct impact on financial performance and firm's value(Hill \& Moroun, 2015). The Lonmin Marikana incident, for example, was an eye opener to the mining industries in respect of human rights and fair treatment of workers. The labour employed at the mining sites was in the poor conditions and under-paid although the company earned hefty profits(Baron, 2013). The incident of Lonmin Marikana mines has garnered international attention after a series of strikes and casualties among the civilians. Post-event investigation revealed that the mining company, Lonmin, had practiced labour exploitation of unfair wages despite the high profit earned by the company (Hill \& Maroun, 2015). 
The after-effect of the incident not only halted key business productions, but had also caused reputational damage to the firm (Chibber, 2012 and Orji,Ogbuabor \& Anthony-Orji 2018).

Based on the series of scandals explained earlier, it can be concluded that financial performance is not the main factors by which the firm is valued. Other non-financial elements such as social and environmental impacts are equally important when assessing the firm's value (Klassen \& McLaughlen, 1996). When making investment decision on the company, investors are beginning to give attention on both financial and non-financial factors(including environmental, social and governance issues)as part of responsible investment measures (Ferrero-Ferrero et al., 2016 and OECD, 2017). Former Vice President of United States, Al Gore (2017), argued that the fiduciary duty of corporations and investor groups in $21^{\text {st }}$ century is to have realistic conscious on the sustainability issues as integral part of business lifecycles. They cannot ignore the need to integrate sustainability practice as part of business culture.

\section{Motivation}

Today, the increasing awareness among public listed companies in Malaysia on the importance of sustainability disclosure have encouraged more companies to disclose its sustainability activities in the annual report. It was on October 2015, Bursa Malaysia issued a guidance document for "Sustainability Statement" where all public listed companies are required to provide disclosure on material economic, environmental and social (ESS) factors in the annual report. As reported by Bursa Malaysia, many companies have started to provide sustainability disclosure in the annual reports although it is not a mandatory requirement (Bursa Malaysia, 2015). All eligible companies identified by Bursa Malaysia are required to provide sustainability disclosure by 2017. Despite the requirement on Sustainability Statement as announced in October 2015 by Bursa Malaysia, prior records had shown that some firms have provided sustainability disclosures in the annual reports much earlier than what is required by regulator. Therefore, it was uncertain whether such disclosures were motivated by the commitment from the board of directors or due to intense pressure from the regulators.

As acknowledged by many scholars, the study on sustainability practices among developing countries is considered scarce (Belal\& Momin, 2009 and Indarawati et. al, 2016). Accordingly, empirical studies that examine the relationship of board diversity on firm's sustainability disclosure from Malaysia's context is also limited (Indarawati et al., 2016 and Omodero \& Ogbonnaya 2018);hence minimal evidence can be used to ascertain whether board diversity had any influence on the voluntary disclosure towards sustainability and environmental practice. Board of directors undoubtedly played important role in shaping and directing the business towards meeting shareholders' objectives of profit maximization, while taking care of the interest of other stakeholders (Donaldson \& Davis, 1991). Therefore, it is vital to contribute towards further study to evaluate the effectiveness of the board in implementing firm's sustainability practices and its contributions towards the environment, society and its shareholders. As such, this study contribute towards existing literatures on the relationship of board diversity on firm's sustainability practice from the context of Malaysia's public listed companies.

The primary objective of this study is to determine the relationship of board diversity and corporate sustainability practice of public listed companies in Malaysia, which was not broadly addressed by the previous researchers. The specific objectives of this study are to directly examine the relationship of each variable of board diversity and corporate sustainability practice, as outlined below:

i. To examine the relationship between board members' age on firm's sustainability practice among public listed companies in Malaysia;

ii. To examine the relationship of board members' gender diversity on firm's sustainability practice among public listed companies in Malaysia;

iii. To examine the relationship of board composition for independent directors on firm's sustainability practice among public listed companies in Malaysia;

iv. To examine the relationship of board capabilities or competencies on firm's sustainability practice among public listed companies in Malaysia; and

v. To examine the relationship of board reputation on firm's sustainability practice among public listed companies in Malaysia.

\section{Literature Review}

\subsection{The Development of Sustainability Practices in Malaysia}

The development of sustainability practice in Malaysia was initiated by government-linked companies (GLCs) through the introduction of "Silver Book" in July 2005. According to Norsyahida and Maliah (2012), the book had 
outlined few initiatives that emphasized the balance between firm's economic performance and social contribution. Although the document had not specified the environmental issues, it was nonetheless highlighted on the need for GLCs to consider the environment as an important means towards social contribution. This move is the reflection of Government's commitment in encouraging GLCs to be more environmental friendly when managing the business affairs. Subsequently, the initiative was further enhanced through the Government's national agenda under the $9^{\text {th }}$ Malaysian Plan for Sustainable Development (Abdullah, 2006).

According to Abdulrazak and Ahmad (2014), the progress of sustainability practices in Malaysia is generally the replication of western-style value system. Although Malaysia is still considered as a developing nation, the government is nonetheless committed in addressing sustainable issues as part of the national agenda (Noranida \& Khairulmaini, 2014). Various interest groups including government agencies, Non-Governmental Organizations (NGOs), regulators, environmental groups and enterprises were joining hands to achieve common goals towards sustainable economic growth for the country. At firms' level, Bursa Malaysia had started the initiative for public listed companies to provide Sustainability Reporting in the annual report beginning from 2017 (Bursa Malaysia, 2015 and Osabohien,et.al 2018). The document superseded the earlier statement on Corporate Social Responsibility (CSR) reporting, which had been practiced by listed companies since 2006. According to Bursa Malaysia (2015), the requirement to provide Sustainability Statement in the annual report is to be implemented on staggered basis over the span of three (3) years period, beginning from 31 December 2016 to 31 December 2018. Selected public listed companies shall disclose its sustainability practice in annual report by 2017 followed by other listed companies, including companies under the ACE Market (Note 1) by 2018.

As acknowledged by Bursa Malaysia (2015), the CSR practices by public listed companies as disclosed in their annual reports were mainly focusing on the social aspect of the business. There was limited impact on value creation because firms' perceptions often inclined towards charitable activities that do not necessarily address sustainability-related concerns to their business operations. In contrary to the firms' perspective, many investor groups nowadays are interested in aligning their investment goal with their personal belief and values. Arising from this belief and values, the concept of "sustainability" became widely accepted among investors groups, since early of this decade, to evaluate whether the conduct of business activities is responsible towards the environment (Lehtonen, 2013 and Peylo, 2014). However, the interpretation and measurement of "sustainability" among scholars are mixed due to several factors such as different regulations or practices adopted by authority bodies among countries(Montiel, 2008 and Preub, 2017); dissimilar focus on specific sustainability issues according to countries/continent/location (Alshuwaikhat, 2005 and Preub, 2017) and divergence among authors' objectives towards field of studies on corporate sustainability practices.In some literatures, the authors had used firm's Corporate Social Responsibility (CSR) disclosures as an interpretation of "sustainability" measurement (Cucari et al., 2017 and Moon, 2007). Meanwhile, Friedman \& Miles.(2001) and Dillenburg et al. (2003) used Socially Responsible Investment (SRI) ratings as firm's sustainability practice. There are also literatures that used Ethical Investment (EI) disclosures as measurement of firm's sustainability practices (Richardson, 2009 and Sparkes, 2001).

Having said this, the Brundtland Report (1987) concluded that sustainability development is the "development that meets the needs of the present without compromising the ability of future generations to meet their own needs" ( $\mathrm{p} .41)$ (Commission on Environment and Development, 1987). Therefore, the interpretation of sustainability can be considered as universal in view of dynamic approaches being used by researches in this subject matter. Looking at Malaysia's context, sustainability reporting as imposed on listed companies was focused on economic, environmental and social (ESS) factors, without the governance element. This is because the comprehensive statement on corporate governance is disclosed separately in the annual report as mandatory disclosure for all public listed companies since 2000 (Oluwaseun \& Boboye 2017and Bursa Malaysia, 2018). The term economic, environmental and social as applied by Bursa Malaysia is adopted from the GRI G4 Sustainability Reporting Guidelines. The key elements of ESS are explained in Figure 1 below: 


\begin{tabular}{|c|c|c|}
\hline Economic & Environmental & Social \\
\hline $\begin{array}{l}\text { An organisation's impacts on } \\
\text { the economic conditions of its } \\
\text { stakeholders and on economic } \\
\text { systems at local, national, } \\
\text { and global levels. It does not } \\
\text { focus on the financial } \\
\text { condition of the organisation. } \\
\text { Note: These may include the } \\
\text { organisation's procurement } \\
\text { practices, or community } \\
\text { investment. }\end{array}$ & $\begin{array}{l}\text { An organisation's impact on } \\
\text { living and non-living natural } \\
\text { systems, including land, air, } \\
\text { water and ecosystems. } \\
\text { Note: These may include the } \\
\text { organisation's usage of energy } \\
\text { and water, discharge of } \\
\text { emissions, or loss of } \\
\text { biodiversity, etc. }\end{array}$ & $\begin{array}{l}\text { The impacts an organisation } \\
\text { has on the social systems } \\
\text { within which it operates. } \\
\text { Note: These may include the } \\
\text { organisation's relationships } \\
\text { with communities, } \\
\text { employees, consumers, etc. }\end{array}$ \\
\hline
\end{tabular}

(Source: Adapted from the GRI G4 Sustainability Reporting Guidelines)

Figure 1. Key Pillars of Bursa Malaysia's sustainability statement

Sustainability disclosures are able to provide additional dimensions on corporate performance that are not captured under the financial data. This will help investors and other stakeholders in making informed decision on the company in a more holistic manner. As such, the board of directors' role, by incorporating sustainability considerations alongside the financial factors; will provide a well-balanced and sound business activities that support the continuity and competitiveness of the firm for long-term basis.

\subsection{The Underlying Characteristics of Board Diversity}

There are many interpretations or determinants of board diversity under the Corporate Governance field. Notwithstanding for the purpose of this study, board diversity will adopt the viewpoint from Securities Commissions of Malaysia. Based on SC's MCGS (2017), board diversity is referred as a mixture of age, gender, experience, education background and skill-sets. Aside from this, the composition of independent directors at the board level will be considered as part of diversity traits.

\subsubsection{Board Age Diversity}

Age diversity of board members is expressed by the co-existence of different generation gaps as well as personal values. Every director of different age groups can embrace and appreciate different experience, cultural norms, habits and personal character that could influence the decision-making process. According to Cucari et al., (2017) based on findings from Ferrero-Ferrero et al. (2016), the age diversity is classified according to several characteristic amongst others including generation based i.e. veteran members, baby boomers or generation X/Y. Ferrero-Ferrero et al.(2016) found that board members' characteristics are the reflection of the era in which they were born or raised; and influenced by the historical period they lived. For example, the veterans are viewed as hard-working and conservative. They are also known to behold strong moral value and supportive towards society's welfare (Post $e t$ al., 2011, Harisson \& Klien, 2007 andHafsi \& Turgut, 2013). Baby Boomers, on the other hand, are seen to be rebellious and radical towards social changes such as civil rights, gender equality or women's movement. While Generation X is seen to be flexible towards technology changes or modern lifestyle, including environmental concern. As such, broader generation group of board members will offer better information resources and broaden the intellectual reasoning for decision making process. In return, board members will take cognizant on the interest of different stakeholders when developing business strategy and corporate policy.

\subsubsection{Board Gender Diversity}

Gender diversity has become one of critical components for effective corporate governance practices in view that it provides equitable and fair business judgement as well as improving the firm's performance (Terjesen et al., 2009 andVafaei et al., 2015). In fact, gender diversity is one of the strategic priorities uphold by Securities Commission to heighten the effectiveness of corporate governance practice among public listed companies in Malaysia (Securities Commission, 2018). The Authority had made its commitment to encourage more public listed companies to increase the participation of women directors at board level, ideally at thirty percent $(30 \%)$ composition. The advantage derived from women participation, as part of diversity elements, could not be denied. Many scholars have agreed that 
gender-based differences are able to offer different viewpoints on leadership styles whereby male leaders tend to be perspective-focused while female leaders usually have soft spot of being emphatic and gentle (Cucari et al., 2017and Onyinye,et.al 2018). Additionally, Corporate Governance Blueprint (2011) provided significant justification, as based on research conducted by McKinsey in 2007, women leaders are more likely to be well-govern. Hence, they will portray good governance practices in the firm. Similarly, previous literatures by Boulouta (2013); Harjoto et al. (2015) and Elmagrhi et al. (2018) agreed that women directors have positive relationship with firm's sustainability practices.

\subsubsection{Board Composition of Independent Directors}

As highlighted by Securities Commission (2011), an effective board should have a well-balanced combination of executive directors (or also identified as inside directors) and non-executive directors (or also identified as outside director) so as to minimize the element of dominant influence; either by individual influence or small group of individuals influence; throughout the decision-making process. Executive directors are entrusted to manage the affairs of the company as they are the one who have direct information about the business dealings while non-executive directors, on the other hand, are commonly associated with oversight roles of the company. As such, having an ideal combination of board composition could help to drive the company democratically as each strategic decisions or firm's actions are being well deliberated by each members of the board. This, in turn, will give better opportunity for the company to expand and progress positively towards achieving the firm's objective (Securities Commission, 2011).

Bursa Malaysia's Listing Requirement (2018) has provided comprehensive guidance on independent directors. They are persons who are independent of management and have no commercial relationship towards the company; so that it will not jeopardize their independent judgement. Chapter 1 -Definition and Interpretation of Bursa Malaysia's Listing Requirement (2018) provided the key criteria to be fulfilled as independent directors. Such information on independent directors is mandatory to be disclosed in the annual report including any personal dealings, shareholding or other directorships. Moreover, Chapter 3 - Admission of Bursa Malaysia Listing Requirement (2018) requires public listed companies to have $1 / 3$ of its board composition to be fulfilled by independent directors. Previous literatures provide mixed results of the role of independent directors on firms' sustainability practices. Scholars such as Cucari et al. (2017); (Ferrero-Ferrero et al. (2016); Harjoto et al. (2015) and Qian et al. (2016) confirmed that independent directors have positive relationship on sustainability disclosure; in view that independent directors are the best device to encourage the firm towards voluntary disclosures. Nonetheless, Lim et al. (2007) found negative relationship between board independence and sustainability disclosures. Perhaps, this was due to the smaller number of independent board members to influence firm's sustainability disclosure.

\subsubsection{Board Capabilities or Competencies}

According to Cucari et al. (2017), ESG can be used as an indicator for management competence, risk management practices and non-financial performance due to the fact that it covers comprehensive sustainability issues on environment (carbon emission, water usage and energy utilization), social (human rights, labour practices, occupational safety and health) and governance (bribery and shareholder protection). As such, it is imperative to investigate board effectiveness on firm's sustainability practices, whether board members provide greater emphasis on sustainability concerns when deliberating on strategic initiatives. Securities Commission (2018) outlines the effectiveness of board when its composition consists of, amongst others; the balanced mix of skills, knowledge and experience. By having these qualities, board will be able to deliberate and challenge constructively on management actions and activities.

Among common motives behind sustainability disclosure is to demonstrate firm's commitment towards the transparency of business activities during the accounting period (Bursa Malaysia, 2015). Therefore, tone at the top is important to provide the right signal to the organization on sustainability practices. Board-level commitment can only be achieved when all members and its executives are well aware on ways to manage sustainability issues in the company. This includes incorporating sustainability consideration into firm's risk management framework and establishes firm-wide policy on sustainability management. A study conducted by Accenture for United Nation (2013) shows that $93 \%$ of CEOs agreed that sustainability is important for future success of their business. As such, sustainability disclosure helps to create corporate values and provides positive impact to the organization (Waddock \& Graves, 1997and Orji,et.al 2018).

\subsubsection{Board Reputation}

Corporate reputation (or inter-changeably as board reputation) is intangible assets that are important to sustain the 
company in the long term. Based on marketing field of study, reputation is referred as firm's image or brand names. Whereas in accounting field of study, reputation is referred as firm's goodwill and trademarks. Therefore, based on the definition put forth, reputation can be assumed as persistent image of the firm throughout its existence or operation (Argenti \& Druckenmiller, 2004). Sustainability practices could create positive and negative images towards the corporation. As such, business strategy developed by the company (or director) must have balanced formula of commercial and sustainability measures, as it will give the (un)desired impact on the firm. According to Smith \& Rupp (2013), (good) reputation is closely related with firm's competitive advantage because society will perceive the company as reliable, trustworthy and able to influence customers' satisfaction.

In addition, firm's sustainability practices are among the factors that influence firm's reputation. Waddock \& Graves. (1997) found that there is a positive relationship between company's reputation and social responsibility ratings. The impact of CSR disclosure would be more apparent on individual clients (or customers) as compared to corporate clients, in view that the CSR activities helps to increase customers' loyalty (Bazillier et al., 2017 and Sontaite-Petkeviciene, 2013). Therefore, it is important to maintain firm's good reputation as a tool to attract resources (e.g. hiring talented directors or management executives) for company's future growth (Cees et al., 2007). It is not uncommon for multinational companies to spend significant amount of money and resources on corporate social activities to boost firm's reputations. For example, companies with over $\$ 8.7 \mathrm{bil}$ of market capitalization had participated under SRI category. Many corporations have acknowledged the importance of sustainability disclosure and hence $81 \%$ companies on Standard \& Poor 500 published their sustainability activities in the annual report (Roselle, 2016).

\subsection{Theoretical Framework}

Based on the literature as discussed in the earlier section, a conceptual framework has been designed to demonstrate the relationship between board diversity characteristics and firm's sustainability practices. In addition, two (2) theories are to be applied for this study, which will be explained in depth in the following section. The theories are the stakeholder theory and the Resource-based View (RBV) theory.

\subsubsection{Stakeholder Theory}

Stakeholder's theory is the main theoretical principle unpinning the corporate governance and sustainability concern which is relevant to this study. This approach followed the earlier consensus in literatures whereby stakeholder theory is the most suited theory to examine firm's sustainability disclosure (Post et al., 2011). The stakeholder theory provides an argument of fiduciary duty of agent towards achieving wealth maximization of the owner while taking care of the interest of other stakeholders. The board of directors have broader responsibilities beyond their fiduciary role towards other interest groups who have legitimate claims of the firm's performance and outcome (Parkinson, 1993);

Critical issues from profit-maximization strategy or overly focus on shareholder theory, which most corporations often disregard are the key implications to the society, economy or the environment. Their standpoints are to please the shareholders for better revenue and other commercial reasons so that shareholders could enjoy profitable investment and good returns. Friedman (1970) asserted that organization does not have moral obligations to consider for other interest groups in view that managers are paid to manage the firm; hence to attain for firm's goal of profit maximization. In order to mitigate problems of shareholder theory, including corporate governance-related issues, agents (in this case refers to board of directors and his executives) have social responsibilities or commitment in balancing the needs of other stakeholders (Freeman, 1994). Their business objectives for revenue generation must be balanced and should not come at the expense of the environment. Therefore, their duty to stakeholders' groups, such as the community and the planet, are equally important without compromising the ultimate needs of the shareholders for long-term wealth maximization.

\subsubsection{Resource-Based View (RBV) Theory}

The RBV Theory is concerned on company's internal strength by giving focus on unique resources that the company possessed such as human capital, strong corporate governance, effective internal control and efficient business process. These resources are exclusively owned by the firm and could not be easily imitated by others (Barney, 1991). Therefore, by having these traits the company can sustain its position in the market and can strive better than its competitors. These unique qualities are known as "competitive advantage" of which could not be found or "purchase" from outside of the company (Barney, 1991). Instead, it only can be attained organically from within the company by optimizing its capabilities and potential for the betterment of the company.

According to Porter (1985), competitive advantage is the key to outperform other firms in the level playing field. 
Indeed, it is a great challenge for every organization to sustain its competitive advantage because firms are often subjected to imitation by its competitors or rival companies. In the strategic management studies, firms may have to face different forces, depending on its intensity or stages of its product lifecycle, in order to sustain in the market. These forces, according to Porter (1985), are referred to barrier to entry, substitute products, rivalry among existing competitors, new entrance, bargaining power of supplier and the bargaining power of buyers. Therefore, most scholars agreed that in order to attain strategic advantage, it must be unique and could not be copied by its rivals.

The RBV Theory has direct relation with Corporate Governance studies in view that the theory relies on firm's competitive advantage as key determinant to outperform competitors (Porter, 1985). Good corporate governance practice will ensure such unique traits that the company has would continue to remain with the company in the long run. It includes the unique resources that the board members possessed such as specialized skills, experience, qualifications, reputation and competencies (Pfeffer \& Salancik, 1979). These qualities of board members will shape the firm's behaviour or culture in driving the company towards sustainability development process (Harjoto et al., 2015 and Smith \& Rupp, 2013).

Figure 2 below explains the overview of theories adopted to examine the relationship of board diversity and firm's sustainability practice (Rao \& Tilt, 2016). Stakeholder theory provides an argument on the role of board of directors to balance the needs of other stakeholders who have claims on the companies; such as employees, suppliers, customers and the public. Whereas the RBV Theory argued on the strategic advantage that the company possessed, which is unique resources that are referred to board diversity traits namely age, gender composition, independent directors, board capabilities or competencies and board reputation.

This strategic advantage is valuable to the company and because the company can perform better than its competitors (Rao \& Tilt, 2016; Barako \& Brown, 2008 and Cucari et al., 2017).

\section{THEORETICAL FRAMEWORK}

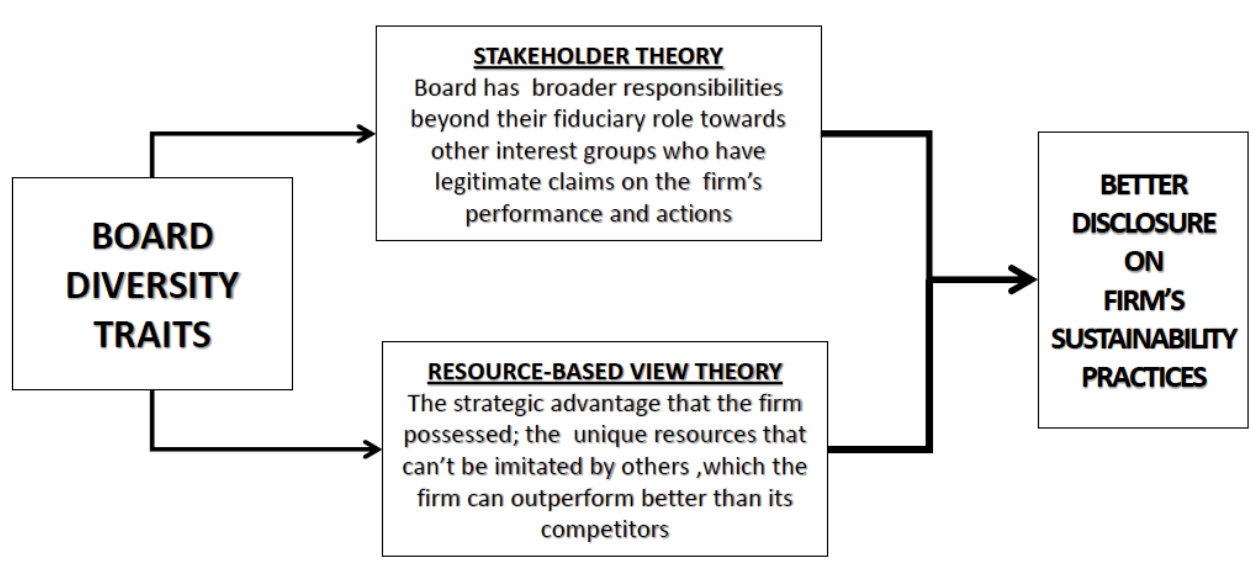

Figure 2. Theoretical framework of board diversity and firm sustainability practices

\subsection{Conceptual Framework}

Based on literature reviews that have been presented in the earlier section, the study outlines the board's diversity traits that rooted from previous empirical research. The diagram below illustrates the relationship of board diversity on firm's sustainability practices. The ESG reporting is a proxy for firm's sustainability practice. The firm's ESG score is a firm's rating which are calculated using the standard parameters or methodology by Thomson Reuters Eikon $^{\mathrm{TM}}$ Datastream. The measurement is based on company-reported data on sustainability practices (such as emission, environmental product innovation, human rights, shareholders, etc.) that are available from the annual report. 
INDEPENDENT VARIABLES

DEPENDENT VARIABLE

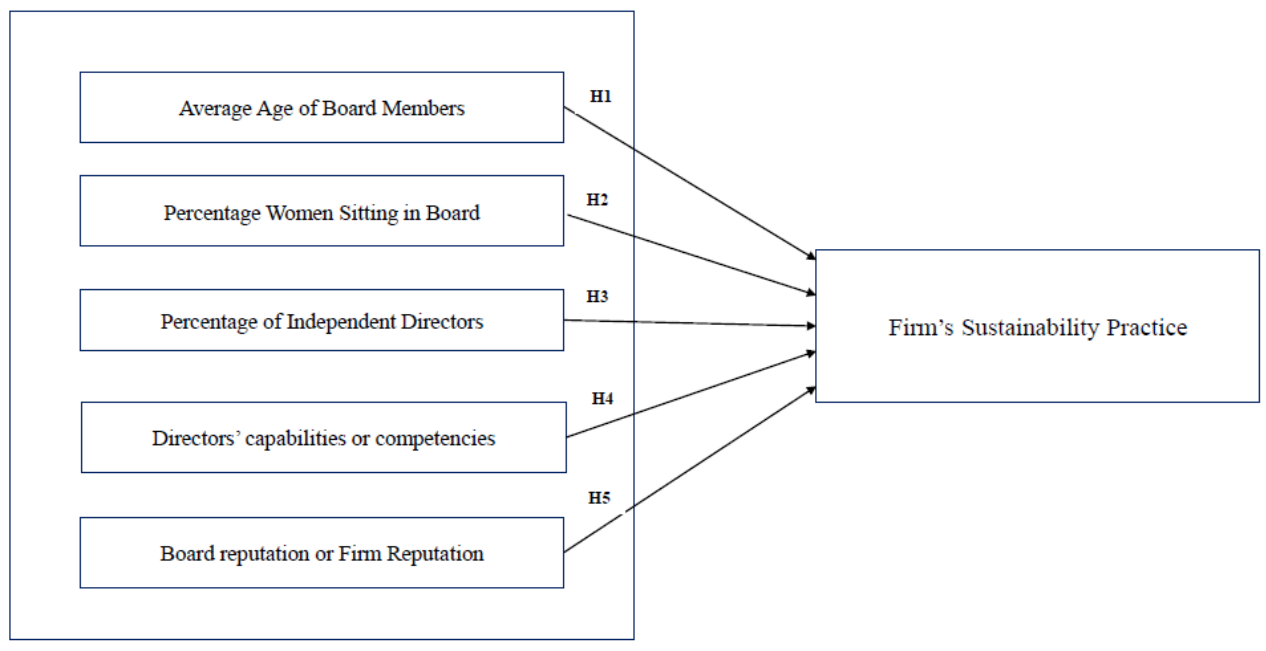

Figure 3. Conceptual framework on the relationship between IVs and DV

Figure 3 explains on the overview of the study. The research framework above shows the independent variables (IVs) that represent board diversity from the RBV Theory. The unique traits or characteristics of board diversity; in this context, are impossible to be imitated by others; namely gender diversity, age groups, composition of independent directors, board capability and board reputation. In addition, the Stakeholder Theory is also demonstrated in this framework, whereby the board of directors are entrusted by shareholders to manage the affairs of the firm, while at the same time not compromising the needs of other interest groups. The dependent variable (DV) is represented by firm's sustainability practices. For the purpose of this study, ESG Combined Score is a proxy that represents firm's sustainability practice. The ESG Combined Score is obtained from Thomson Reuters Eikon ${ }^{\mathrm{TM}}$ Datastream.

Based on the diagram above, the study will demonstrate the relationship of board diversity on corporate sustainability practice. This concept is following the previous empirical study by Cucari et al. (2017) and Rao \& Tilt (2016) in examining board diversity and firm's sustainability practice. In addition, the conceptual framework for this study is constructed in a manner to explain the adoption of theories to examine the board diversity characteristics towards firm's sustainability practice, through ESG Reporting.

\subsection{Hypotheses Development}

The hypotheses for this study are presented and explained in the following sub-sections.

\subsubsection{Board age diversity}

One of the traits to explain diversity of the board is by looking at the average age of board members and senior management (Securities Commission, 2017). Age diversity of board members is expressed by way of the co-existence of different generation gaps as well as personal values. On the different age gaps, every director can embrace and appreciate different experience, cultural norms, habits, character or goals that could influence the decision-making process (Cucari et al., 2017). While senior directors are known to have vast experience, skill and competencies; younger directors on the other hand, are acknowledged as open-minded, dynamic and eager towards technological a centric (Harjoto et al., 2015). Nevertheless, age is often associated with environmental attitude or knowledge on environmental issues (Rao \& Tilt, 2016), whereby older generations are conservative towards sustainability practice.

Ferrero-Ferrero et al. (2016) categorised the age gaps as reflection towards their personal characteristic according to the period they were raised (whether they were Traditionalist, Baby Boomers, Gen X or Millennials). The findings revealed that there was a positive relationship between the generation diversity and firm's diversity performance. Another scholar, Post et al. (2011), found that firm will score highest sustainability rating when the average age of board members is 56 years old. Contrary to the earlier findings on age diversity, Giannarakis (2015) and Barako \& Brown (2008) found negative relationships of board age diversity with firm sustainability disclosure. Hence, based on the mixed-results of literature findings mentioned above, this study proposes the following hypotheses: 
$\mathrm{H}_{1}$ : There is a significant relationship between board members' age on firm's sustainability practices among public listed companies in Malaysia.

\subsubsection{Board Gender Diversity}

Another characteristic to describe board diversity is by gender representation. Many have argued that diverse board in terms of proportion between female directors and male directors could create balanced perspectives on humanity factors involving firm's strategic decision making. Hence, mixed literatures suggested on the effect of women directors on sustainability practices. Firstly, there is a positive relationship between women directors on sustainability practice in view of women directors often encourage companies to adopt more socially responsible approach (Post et al., 2011). The literature suggested that when more women sit at the board, the more their board members to act towards socially responsible ways as compared with single-gender board or fewer woman at the board (Adams et al., 2015). In contrast to the findings as mentioned earlier, Giannarakis (2015) revealed that there is negative relationship between gender diversity and sustainability practices. Hence, women directors would not be the determinant of corporate sustainability disclosure when their participation at boardroom is small. Therefore, based on the above reasoning, this study proposes the following hypotheses:

$\mathrm{H}_{2}$ : There is a significant relationship of board members' gender diversity on firm's sustainability practicesamong public listed companies in Malaysia.

\subsubsection{Board Composition of Independent Directors}

Thirdly, the commonly used variables in the corporate governance literature to explain on the board diversity elements are the composition of independent directors or non-executive members. The independent directors' role not only helps towards the firm's implementation of sustainability initiatives, but it rather positively related to the degree of voluntary disclosure and transparency of reporting (Wang, 2017). In fact, there are numbers of empirical studies that explains relationship of independent directors with CSR reporting to promote stakeholder's interest (Barako \& Brown, 2008 and Ho \& Wong, 2001). Independent directors are often requested for additional information or disclosure to be provided in the annual report, thus encouraging executive managers to provide detailed disclosure of sustainability practices. However, Eng \& Mak (2003) found that outside director is negatively related to voluntary disclosure for Singapore public listed companies. Non-relationship between independent directors and firm sustainability reporting could be due to other contributory factors such as board's lack of skills or experience, unfamiliarity with business model or due to regulatory pressure on the voluntary disclosure (Handajani $e t$ al., 2014). As such, the study proposes the following hypotheses:

$\mathrm{H}_{3}$ : There is a significant relationship of board composition for independent directors on firm's sustainability practices among public listed companies in Malaysia.

\subsubsection{Board Capabilities or Competencies}

Cucari et al. (2017) asserted that voluntary disclosure can be used to assess firm's competencies in managing the affairs of the company during the financial period through non-financial statements in the annual report such as Sustainability Statement and Corporate Governance Statement. Therefore, Waddock \& Graves (1997) agreed that firm performance is increased in tandem with sustainability disclosures because customers, client and investors able to see firm's achievements during the year. Looking at this context, it can be said that board competencies is often associated with firm's performance. A competent board (and its executives) will strive towards achieving good (firm) performance. Therefore, there is a positive relationship between board capabilities with firm's sustainability disclosure (Peiris \& Evans, 2010). Another literature by Peiro-Signes et al. (2013) and Aouadi \& Marsat (2016) also agreed that a good sustainability practice improves firm performance and reputation. On the other hand, Oikonomou et al. (2012) found that the firm's sustainability practice has negative relationship with firm performance. Therefore, the hypothesis is proposed as follows:

$\mathrm{H}_{4}$ : There is a significant relationship of board capabilities or competencies on firm's sustainability practices among public listed companies in Malaysia.

\subsubsection{Board Reputation}

Firm reputation depends mainly on corporate past actions and positive future estimates relative to its rivals. Accordingly, this can be translated by the actions and commitment of its directors or executives in managing the business affairs in the eye of key stakeholders including employees, customers, suppliers, regulators and general public. As such, appointing rightful people with strong characteristics and reputation can help to influence outsiders' perceptions on the firm (Pfeffer \& Salancik, 1978 and Bear et al., 2010). 
In addition, sustainability-related controversy issues such as child exploitation, prohibited business conduct or skin-color discrimination as practiced by some multinational corporations could affect their reputation and brand image (Melewar, 2010). Ultimately, these adverse remarks or controversies could affect their firm performance or firm values (Cai et al., 2012 and Aouadi \& Marsat, 2016). Although there are also contrary results found on the relationship between board reputation and firm's sustainability disclosure as noted by Oikonomou et al. (2012), the hypothesis of this study is proposed as follows:

$\mathrm{H}_{5}$ : There is a significant relationship of board reputation on firm's sustainability practices among public listed companies in Malaysia.

\section{Research Methodology and Design}

The data collection in this study involved rigorous search of Thomson Reuters ESG Scores of public listed companies in Malaysia, which sourced from Thomson Reuters Eikon ${ }^{\mathrm{TM}}$ Datastream. The datastream provided three types of ESG scoring index namely ESG Combined Score, ESG Score and ESG Controversies Score of public listed companies that provide sustainability disclosures in the financial report. The Thomson Reuters ESG Scores is an enhanced sustainability rating model that replaced of the existing Thomson Reuters ASSET4® Equal Weighted Ratings (EWR) DataStream. The new Thomson Reuters Eikon ${ }^{\mathrm{TM}}$ Datastream provides ESG data streams of companies globally with comprehensive ESG metrics from data history from year 2002 until present.

The time horizon of ESG data extracted for this study was performed between April 2018 to August 2018. A total of fifty-two (52) Malaysian listed companies disclosed its ESG practice in the annual report, based on the datastream search conducted from April 2018 to August 2018 from Thomson Reuters Eikon ${ }^{\mathrm{TM}}$. However, only thirty-eight (38) companies provided constant disclosures of ESG practice during the period of study between FYE 2010 to FYE 2016. Thus, elimination of incomplete sample periods was performed and only the thirty-eight (38) companies were chosen as final samples for the study. Whereas the remaining fourteen (14) listed companies just started its ESG disclosures for less than 3 years, hence were excluded from the final sample.

\subsection{Data Collection Method}

For the purpose of this study, the data were gathered from two (2) sources namely Thomson Reuters Eikon ${ }^{\mathrm{TM}}$ Datastream and the published annual report of the respective companies that are available in their official websites. The main data extracted from respective sources were summarised as per figure below:

\begin{tabular}{|c|c|}
\hline Source & Information Obtained \\
\hline Thompson Reuters Eikon ${ }^{\mathrm{TM}}$ Datastream & $\begin{array}{l}\text { Firms' ESG Scores, firm's ESG Combined Score and } \\
\text { firm's ESG Controversies Score }\end{array}$ \\
\hline Published annual reports & $\begin{array}{l}\text { Board composition (namely women participation in } \\
\text { board and independent directors) and board members' } \\
\text { age. The information was extracted from Director's } \\
\text { Profile information available from published annual } \\
\text { report. }\end{array}$ \\
\hline
\end{tabular}

Figure 4. Source of data collected

In total, there were five (5) independent variables and one (1) dependent variable represented in unit of firm's ESG Combined Score obtained from the datastream. The Statistical Package for Social Science (SPSS) software version 16 is used to analyse the data collected from this study. SPSS programme is useful in analysing and examining the hypotheses as formulated in the earlier section. Therefore, the relationships that are analyzed can be expressed using the following equation:

The model used is as follows:

$$
\hat{y}=\widehat{\beta_{0}}+\widehat{\beta_{1}} x_{1}+\widehat{\beta_{2}} x_{2}+\widehat{\beta_{3}} x_{3}+\widehat{\beta_{4}} x_{4}+\widehat{\beta_{5}} x_{5}
$$

Where $\beta_{0}$ is constant coefficient of regression, and $\beta_{1}-\beta_{5}$ represents regression coefficient of independent variables. Hence, the variable definitions are provided as below:

$\mathrm{Y}=$ ESG Combined Score (as proxy for firm's sustainability disclosure);

$x_{1}=$ Average age of board members 
$x_{2}=$ Percentage of women sitting at the Board level;

$x_{3}=$ Percentage of independent directors;

$x_{4}=$ ESG Score (as proxy for board capabilities or competencies); and

$x_{5}=$ ESG Controversies Score (as proxy for board reputation).

\section{Results and Discussion}

\subsection{Normality Test}

The normality tests for this study were performed using the Kolmogorov-Smirnov Test and the Shapiro-Wilk Test. The result generated from these tests we presented in Table 1.

Table 1. Normality of data

\begin{tabular}{lllllll}
\hline Variables & \multicolumn{7}{l}{ Kolmogorov-Smirnov } & \multicolumn{4}{l}{ Shapiro-Wilk } \\
\cline { 2 - 7 } & Statistic & $\mathbf{d f}$ & Sig. & Statistic & $\mathbf{d f}$ & Sig. \\
\hline Age & 0.069 & 266 & 0.004 & 0.973 & 266 & 0.000 \\
\hline Women_at_Board & 0.243 & 266 & 0.000 & 0.860 & 266 & 0.000 \\
\hline Independent_Directors & 0.210 & 266 & 0.000 & 0.852 & 266 & 0.000 \\
\hline ESG_Score & 0.084 & 266 & 0.000 & 0.970 & 266 & 0.000 \\
\hline ESG_Controversies & 0.266 & 266 & 0.000 & 0.623 & 266 & 0.000 \\
\hline ESG_Combined & 0.076 & 266 & 0.001 & 0.975 & 266 & 0.000 \\
\hline
\end{tabular}

Table 1 above represents the data normality according to the value of results from the Kolmogorov-Smirnov Test and the Shapiro-Wilk Test. For the purpose of this study, the Shapiro-Wilk Test is more appropriate to be adopted for small sample sizes. The Shapiro-Wilk Test is commonly used for small sample size as little as 30 samples; but can handle larger sample size of up to 2000 samples (Field, 2013). Hence, for this reason the Shapiro-Wilk test is used as numerical means for assessing normality. Hence, the result of normality test conducted is presented in the Table 2 below:

Table 2. Result of normality test

\begin{tabular}{llll}
\hline Variable & Sig. & Decision Rule & Conclusion \\
\hline Age & 0.000 & $<\mathrm{T} 0.05$ & The distribution is not normal. \\
\hline Women_at_Board & 0.000 & $<\mathrm{T} 0.05$ & The distribution is not normal. \\
\hline Independent_Directors & 0.000 & $<\mathrm{T} 0.05$ & The distribution is not normal. \\
\hline ESG_Score & 0.000 & $<\mathrm{T} 0.05$ & The distribution is not normal. \\
\hline ESG_Controversies & 0.000 & $<\mathrm{T} 0.05$ & The distribution is not normal. \\
\hline ESG_Combined & 0.000 & $<\mathrm{T} 0.05$ & The distribution is not normal. \\
\hline
\end{tabular}

Based on the Shapiro-Wilk test for the normality, all the variables are not normally distributed as the value are less than 0.05 . Nevertheless, since the total data is 266 and can be categorized as a large data set; hence, it is normally distributed (McClave, 2008)for each independent variable namely Age, Women_at_Board, Independent_Directors, ESG_Score, ESG_Controversies and ESG_Combined.

\subsection{Auto Correlation}

Autocorrelation, also known as serial correlation, provides the analysis whether the elements of a time series are positively correlated, negatively correlated or independent of each other. Table 3 provides the results of autocorrelation. 
Table 3. Model summary : untransformed multiple linear regression

\begin{tabular}{lllll}
\hline Model & R Square & Adjusted R Square & Durbin Watson & P-Value \\
\hline 1 & $0.971^{\mathrm{a}}$ & 0.971 & 9.971 & 0.000 \\
\hline
\end{tabular}

Predictors (Constant): Age, Women_at_Board, Independent_Directors, ESG_Score, ESG_Controversies, Dependent Variable: ESG_Combined

From Table 3 above, the model summary shows a low $\mathrm{R}^{2}$ value which is more than $60 \%$. A high $\mathrm{R}^{2}$ value interprets the variation in the response variable that can be explained by the predictor. The $\mathrm{R}^{2}$ value explains that $97.1 \%$ of the variation in the Dependent Variable, which represented by ESG Combined Score, is explained by the Independent Variables (namely Age, Women at Board, Independent Directors, ESG Score and ESG Controversies). The Durbin-Watson statistic lies in the range 0 to 4 .A value of 2 or nearly 2 indicates that there is no first-order autocorrelation. An acceptable range is $1.50-2.50$. Since the value of Durbin Watson for the model is between the ranges, it can be concluded that there is no autocorrelation. Where successive error differences are large, Durbin-Watson is high (more than 2.50); this indicates the presence of negative autocorrelation. Negative autocorrelation is not particularly common. The p-value which is less than significant value (0.05) indicates that the model is significant.

Therefore, the multiple linear regression equation model is presented as below:

$$
\hat{y}=\widehat{\beta_{0}}+\widehat{\beta_{1}} x_{1}+\widehat{\beta_{2}} x_{2}+\widehat{\beta_{3}} x_{3}+\widehat{\beta_{4}} x_{4}+\widehat{\beta_{5}} x_{5}
$$

Where:

$\mathrm{Y}=$ ESG Combined Score

$x_{1}=$ Age

$x_{2}=$ Women at Board

$x_{3}=$ Independent Directors

$x_{4}=$ ESG Score

$x_{5}=$ ESG Controversies

\subsection{Multiple Linear Regressions}

Multiple linear regression attempts to model the relationship between two or more explanatory variables and a response variable by fitting a linear equation to the observed data. Every value of the independent variable is $x$ is associated with a value of the dependent variable $y$.

\subsubsection{Model Fitting}

Table 4. Model coefficients for multiple linear regression

\begin{tabular}{llll}
\hline $\begin{array}{l}\text { Dependent } \\
\text { Variable }\end{array}$ & Independent Variables & $\boldsymbol{\beta}$ & Sig. \\
\hline & Constant & -29.312 & 0.000 \\
\cline { 2 - 4 } & $x_{1}$ (Age) & 0.173 & 0.000 \\
\cline { 2 - 4 } ESG Combined & $x_{2}$ (Women_at_Board) & 0.000 & 0.956 \\
\cline { 2 - 4 } & $x_{3}$ (Independent_Directors) & 0.019 & 0.058 \\
\cline { 2 - 4 } & $x_{4}$ (ESG_Score) & 0.959 & 0.000 \\
\cline { 2 - 4 } & $x_{5}$ (ESG_Controversies) & 0.321 & 0.000 \\
\hline
\end{tabular}

Table 4 shows the regression result of the basic equation which consist of independent and dependent variables. Based on $\mathrm{t}$, the significant value (or p-value) indicates the degree of significant relationship between independent variables (or predictors) with dependent variable which could be explained by using the rule of thumb of p-value less than 0.5 $(<.05)$. From the table above, board age (Age), board capabilities (ESG_Score) and board reputation 
(ESG_Controversies) are associated with firm's sustainability practices (ESG_Combined). The Age, ESG_Score and ESG_Controversies are significantly positive towards the dependent variable since the p-values $<\alpha(0.05)$.

In other words, this means that the board members' age, their capabilities and reputation played important role towards firm's sustainability practices. This result is consistent with Cucari (2017) for gender diversity; Post et al. (2011) for board capabilities and Rao\& Tilt (2016) for board reputation. These scholars supported the argument that age diversity, board competencies and board reputation are associated with firm's sustainability practices.

Diverse board members with different age group will represent better perspective on sustainability issues effectively (Harjoto et al., 2015). In addition, board reputation has influence towards firm's sustainability practice (Cai et al., 2012). This is because board with strong conscious on the environment and social issues will manage the company diligently and any bad decision will bring the company towards poor reputation, which eventually will affect the sustainability scoring by rating agencies (Auer\& Schumacher, 2016)

The equation model is tested further to assess its sensitivity and presented as follows:

$$
\begin{aligned}
y(\text { ESG Combined }) & =-29.312+(0.173) \text { Age }+(0.000) \text { Women at Board } \\
& +(0.019) \text { Independent Directors }+(0.959) \text { ESG Score } \\
& +(0.321) \text { ESG Controversies }
\end{aligned}
$$

From the equation above, it can be concluded that the significant variances are as per below:

- $\quad \beta_{0}=-29.312$. When all the predictor variables are held constant, the ESG_Combined, as the measurement of firm's overall sustainability practice, will be at -29.312 points.

- For every increase of board members' age by one (1) year, the ESG_Combined Score will increase by 0.173 points.

- $\quad$ For every increase in ESG Score by one (1) point, the ESG_Combined Score will increase by 0.959 points.

- For every increase in ESG Controversies Score by one (1) point, the ES_GCombined will increase by 0.321 points.

\subsection{Pearson's Correlation}

Table 5. Pearson's correlation

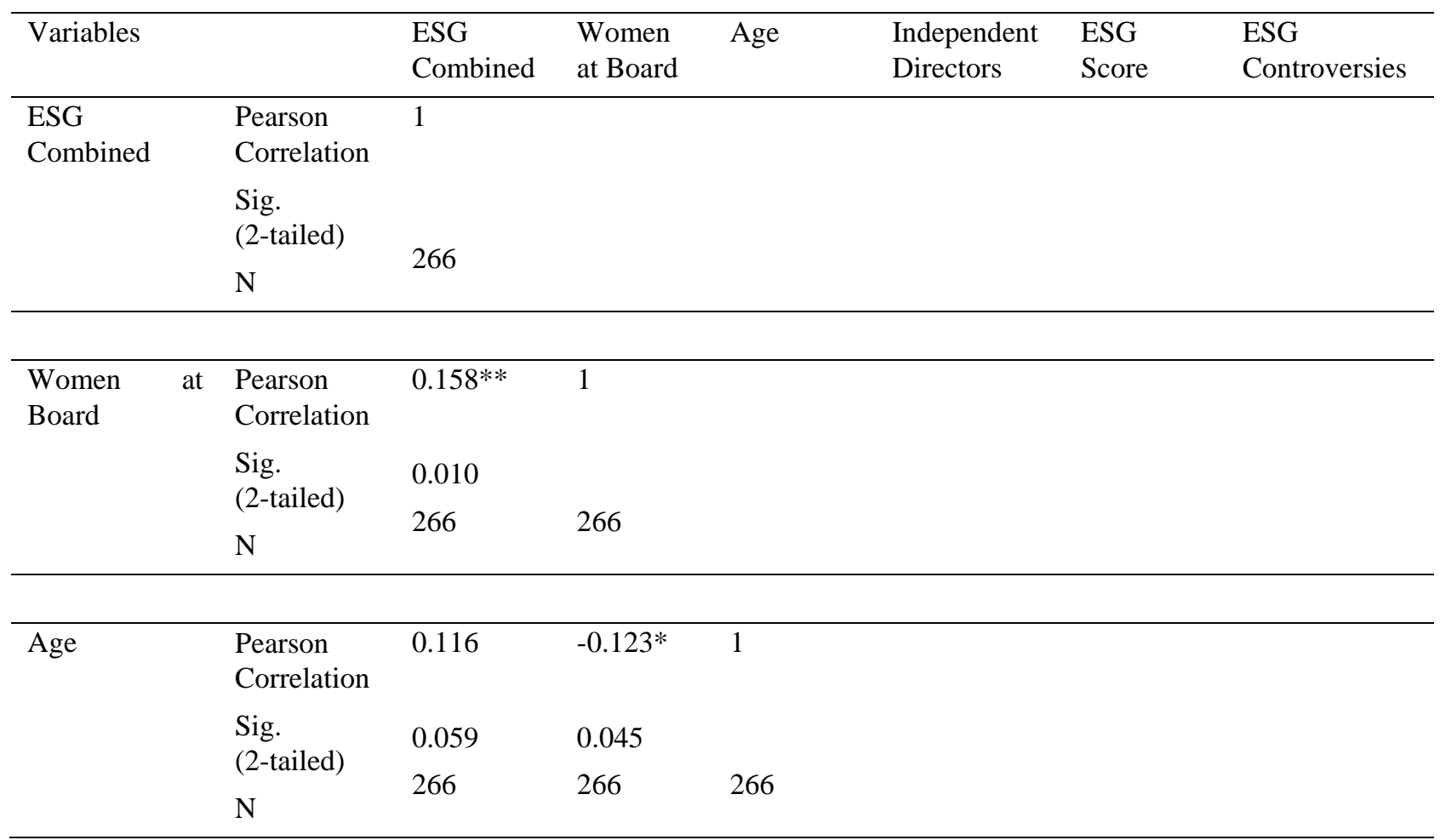




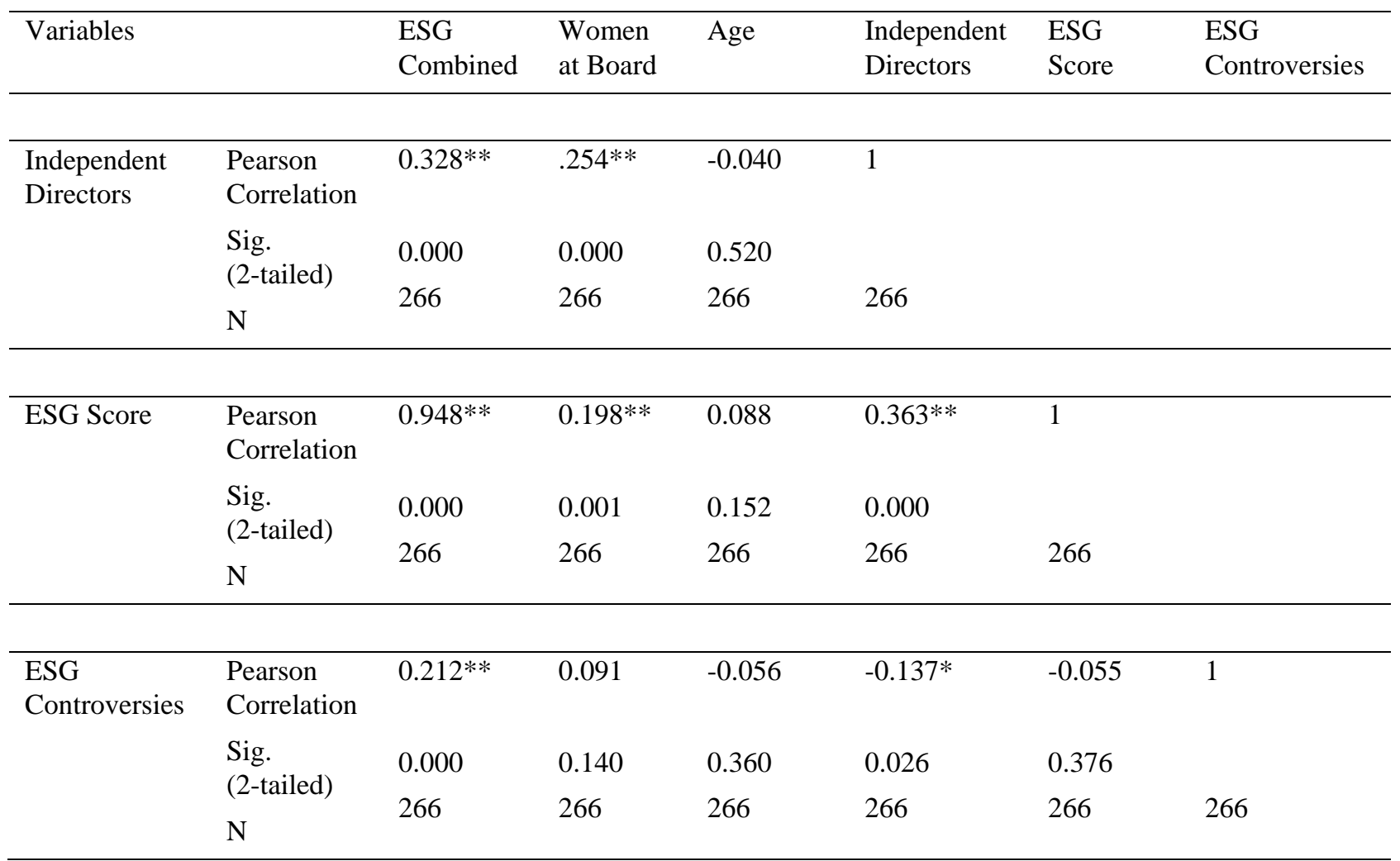

**. Correlation Is Significant at the 0.05 Level (2-Tailed)

Table 5 above represents the Pearson's Correlation analysis of the results for all variables used for this study. Based on above table, the correlation between dependent and independent variables shows that there is a strong correlation between ESG Score and ESG Combined Score, whereby the $r_{=} .948$ and $p$-value $=0.000$. This means that there is a strong relationship between board capabilities or competencies and firm's sustainability practices. Meanwhile, there is a medium correlation between ESG Combined Score and Independent Directors (where $r=0.328, p$-value $=0.000$ ). Whereas for gender diversity $(r=0.158)$ and ESG_Controversies $(r=0.212)$ have weak positive correlations with ESG Combined Score. Lastly, the board members' age has no correlation with ESG Combined Score.

In summary, the results achieved according to the hypotheses development for this study is presented as per Table 6 below:

Table 6. Summary on result of hypotheses

\begin{tabular}{lll}
\hline No. & Hypotheses & Result \\
\hline $\mathrm{H}_{1}$ & $\begin{array}{l}\text { There is a significant relationship between board } \\
\text { members age on firm's sustainability practices } \\
\text { among public listed companies in Malaysia }\end{array}$ & \\
\hline $\mathrm{H}_{2}$ & $\begin{array}{l}\text { There is a significant relationship of board members' } \\
\text { gender diversity on firm's sustainability practices }\end{array}$ & \\
& among public listed companies in Malaysia & \\
\hline $\mathrm{H}_{3}$ & $\begin{array}{l}\text { There is a significant relationship of board } \\
\text { composition for independent directors on firm's }\end{array}$ & \\
& $\begin{array}{l}\text { sustainability practice among public listed companies } \\
\text { in Malaysia }\end{array}$ & \\
\hline $\mathrm{H}_{4}$ & $\begin{array}{l}\text { There is a significant relationship of board } \\
\text { capabilities or competencies on firm's sustainability }\end{array}$ & \\
\hline
\end{tabular}




\begin{tabular}{lll}
\hline No. & Hypotheses & Result \\
\hline $\mathrm{H}_{5}$ & practice among public listed companies in Malaysia & \\
\hline & $\begin{array}{l}\text { There is a significant relationship of board reputation } \\
\text { on firm's sustainability practices among public listed } \\
\text { companies in Malaysia }\end{array}$ & Supported \\
\hline
\end{tabular}

\section{Conclusion}

This study is designed to examine the relationship of board diversity on firm's sustainability practice from the perspective of Malaysian public listed companies. The primary reason of selecting this topic area, in particular on firm's ESG disclosure, was due to limited empirical studies performed on public listed companies in Malaysia, despite the ESG concerns have become the latest sustainability challenge among companies at international level. In order to achieve the study objective, multiple linear regression test was conducted on five (5) independent variables namely average age of board members (Age), gender diversity (Women_at_Board), board composition of independent directors (Independent_Directors), board capabilities or competencies (ESG_Score) and board reputation (ESG_Controversies) and dependent variable namely firm's ESG disclosure (ESG_Combined). The sample selection was mainly obtained from Thomson Reuters Eikon ${ }^{\mathrm{TM}}$ Datastream, which provided the list of public listed companies with ESG scores. The total lists of companies with ESG Scores available from the datastream were 52 companies. Nevertheless, after a careful examination for the completeness of data, only 38 public listed companies were selected as final sample based on historical record with consistent ESG scores for the period of 7-years from 2010 to 2016. Based on the result generated, it can be concluded that three $(3)$ hypotheses $\left(\mathrm{H}_{1}\right.$ : Board age has positive relationship with firm's sustainability practice, $\mathrm{H}_{4}$ : Board competencies or capabilities have positive relationship on firm's sustainability practice and $\mathrm{H}_{5}$ : Board reputation have positive relationship on firm's sustainability disclosure) were successfully met, based on the fact three (3) out of five (5) hypotheses supported the assumptions. The result is also consistent with the study performed by Rao \& Tilt (2016) and Post et al. (2011)in examining the influence of board members' age.

Findings of positive relationship between board capabilities and firm sustainability disclosure is consistent with the result by Cucariet al. (2017); Waddock \& Graves (1997) and Aouadi \& Marsat (2016). This means that board capability is the driving factor to lead the organization towards better disclosure on sustainability practice. Accordingly, board reputation is a mirror to portray firm's sustainability practice. In other words, when sustainability concern becomes integral part of firm's operation, hence firm reputation is improved. This promulgation is consistent with Waddock \& Graves (1997) and Bazillier et al. (2017). In conclusion, it can be said that, based on the findings from this study, board diversity is among the key elements to influence firm's sustainability disclosure with $97.1 \%$ $\left(\mathrm{R}^{2}\right.$ and adjusted $\left.\mathrm{R}^{2}\right)$ of the variation in firm's sustainability disclosure is explained by board diversity.

This study helps to provide additional viewpoint of firms' sustainability practices in Malaysia through the adoption of ESG factors; by giving focus on the role of the board of directors. Although Malaysia had just started to impose requirement on listed companies for sustainability reporting beginning year 2016 (Bursa Malaysia, 2015), it is nonetheless an optimistic progress towards sustainable development for our nation. Below are perhaps some contributions that can provide few leads to the following interest parties on sustainability concerns.

\section{Acknowledgement}

We wish to thank the Institute of Quality and Knowledge Advancement and the Institute of Research Management and Innovation of Universiti Teknologi MARA for their support and funding.

\section{References}

Abdullah, A. B. (2006). Ninth Malaysia Plan 2006-2010. Putrajaya: Prime Minister Office.

Abdulrazak, S., \& Ahmad, F. (2014). Sustainable development: A Malaysian perspective. Procedia - Social and Behavioral Sciences, 164, 237-241. https://doi.org/10.1016/j.sbspro.2014.11.072

Adams, R. D. (2015). Board Diversity: Moving the field forward. Corporate Governance: An International Review, 23(2), 77-82. https://doi.org/10.1111/corg.12106

Alshuwaikhat, H. (2005, May). Strategic environmental assessment can help solve environmental impact assessment failures in developing countries. Enviromental Impact Assessment Review, 25(4), 307-317. https://doi.org/10.1016/j.eiar.2004.09.003 
Aouadi, A., \& Marsat, S. (2016). Do ESG Controversies Matter for Firm Value. Journal of Business Ethics, 151(4), 1027-1047. https://doi.org/10.1007/s10551-016-3213-8

Arayssi, M. D. (2016). Women on boards, sustainability reporting and firm performance. Sustainability Accounting, Management and Policy Journal, 7(3), 376-401. https://doi.org/10.1108/SAMPJ-07-2015-0055

Argenti, P. (2004). Reputation and the corporate brand. Corporate Reputation Review, 6(4), 368-374. https://doi.org/10.1057/palgrave.crr.1540005

Auer, R. B. (2016). Do Socially (Ir)responsinble Investment Pay? New Evidence From International ESG Data. The Quarterly Review of Economics and Finance, 51-62. https://doi.org/10.1016/j.qref.2015.07.002

Barako, D. G. (2008). Corporate social reporting and board representation: evidence from the Kenyan banking sector. Journal of Management and Governance, 12(4), 309-324. https://doi.org/10.1007/s10997-008-9053-x

Barney, J. (1991). Firm resources and sustained competitive. Journal of Management, 17(1), 771-792. https://doi.org/10.1177/014920639101700108

Baron, P. (2013). The Root and Responsibility Model: A Framework for Ethical Consumption. Kybernetes, 1325-1337. https://doi.org/10.1108/K-10-2012-0086

Bazillier, R. H. (2017). Are Environmentally Responsible Firms Less Vulnerable When Investing Abroad? The Role of Reputation. Journal of Comparative Economics, 520-543. https://doi.org/10.1016/j.jce.2016.12.005

Bear, S. R. (2010). The Impact of Board Diversity and Gender Composition on Corporate Social Responsibility and Firm Reputation. Journal of Business Ethics, 207-221. https://doi.org/10.1007/s10551-010-0505-2

Belal, A., \& Momin, M. (2009). Corporate social reporting (CSR) in emerging economies: A review and future direction. Accounting \& Accountability https://doi.org/10.1108/S1479-3563(2009)0000009007

Boulouta, I. (2013, March). Hidden Connections: The Link Between Board Gender Diversity and Corporate Social Performance. Journal of Business Ethics, 113(2), 185-197. https://doi.org/10.1007/s10551-012-1293-7

BP Exploration \& Production Inc. (2015). Gulf of Mexico Environmental Recovery and Restoration - 5 Year Plan. BP Exploration \& Production Inc. N/A: BP. Retrieved 17 September, 2018, from https://www.bp.com/content/dam/bp-country/en_us/PDF/GOM/BP_Gulf_Five_Year_Report.pdf

Broome, L. C. (2009). Dangerous Categories: Narratives of Corporate Board Diversity. North Carolina Law Review, $89,760-808$.

Brown, K. H. (2012). Governance, Media and the Quality of Environmental Disclosure. Journal of Accounting and Public Policy, 610-640. https://doi.org/10.1016/j.jaccpubpol.2012.09.002

Bursa Malaysia. (2015). Bursa Malaysia Sustainability Reporting Guide. Kuala Lumpur: Bursa Malaysia.

Bursa Malaysia. (2018). Bursa Sustain. Retrieved from https://bursasustain.bursamalaysia.com/droplet-details/resources/ftse4good-bursa-malaysia-index

Cai, Y. J. (2012). Doing Well While Doing Bad? CSR in Controversial Industry Sectors. Journal of Business Ethics, 467-480. https://doi.org/10.1007/s10551-011-1103-7

Cees, B. M. (2007). Essentials of Corporate Communication: Implementing Practices for Effective Reputation Management. London: Routledge.

Chibber, K. (20 August, 2012). Mining Investors Take Stock After Marikana Death. Retrieved from https://www.bbc.com/news/business-19316846

Commission on Environment and Development. (1987). Report of the World Commission on Environment and Development: Our Common Future. Harlem Brundtland: Commission on Environment and Development. https://doi.org/10.3828/twpr.9.3.x4k73r2p72w22402

Commission, S. (2011). Corporate Governance Blueprint 2011: Towards Excellence in Corporate Governance. Kuala Lumpur.

Companies, P. A. (2013). ESG transparency as competitive advantage for listed companies. Warszaw: Polish Association of Listed Companies (SEG).

Cruden, J. O. (2016). The Deepwater Horizon Oil Spill Litigation: Proof of Concept for the Manual for Complext Litigation and the 2015 Amendments to the Federal Rules of Civil Procedure. Michigan Journal of 
Environmental \& Administrative Law, 6(1), 65-149.

Cucari, N. D. (2017). Diversity of board of directors and Enviromental Social Governance: Evidence form Italian listed companies. Corporate Social Responsibility and Environmental Management. https://doi.org/10.1002/csr.1452

Dillenburg, S. G. (2003). Approaching socially responsible investment with a comprehensive ratings scheme: Total social impact. Journal of Business Ethics, 43(3), 167-177. https://doi.org/10.1023/A:1022987127960

Donaldson, L., \& Davis, J. (1991). Stewardship Theory or Agency Theory: CEO Governance and Shareholder Returns. Australian Journal of Management, 49-65. https://doi.org/10.1177/031289629101600103

Elmagrhi, M. H. (2018). A study of environmental policies and regulations, governance structures and environmental performance: The role of female directors. Business Strategy and the Environment, (28), 206-220. https://doi.org/10.1002/bse.2250

Eng, L., \& Mak, Y. T. (2003). Corporate governance and voluntary disclosure. Journal of Accounting and Public Policy, 22(4), 325-345. https://doi.org/10.1016/S0278-4254(03)00037-1

Ferrero-Ferrero, I. F.-I.-T. (2016). The Effect of Environmental, Social and Governance Consistency on Economic Results. Sustainability, 1-16. https://doi.org/10.3390/su8101005

Field, A. (2013). Discovering Statistics Using SPSS. Los Angeles: SAGE.

Freeman, R. E. (1994, October). The Politics of Stakeholder Theory: Some Future Directions. Business Ethics Quarterly, 4(4), 409-421. https://doi.org/10.5840/10.2307/3857340

Friedman, L. A. (2001, December). Socially Responsible Investment and Corporate Social and Environmental Reporting in the UK: An exploratory Study. The British Accounting Review, 33(4), 532-548. https://doi.org/10.1006/bare.2001.0172

Friedman, M. (1970, September 13). The social responsiblity of business is to increase its profits. New York Times Magazines.

Giannarakis, G. (2015). The determinants influencing the extent of CSR disclosure. International Journal of Law and Manangement, 56(5), 393-416. https://doi.org/10.1108/IJLMA-05-2013-0021

Gore, A. (2018, April 19). Fiduciary Duty in the 21st Century. Retrieved from https://www.unpri.org/fiduciary-duty/al-gore-introduces-fiduciary-duty-in-the-21st-century/245.article

Hafsi, T., \& Turgut, G. (2013). Boardroom Diversity and its Effect on Social Performance: Conceptualization and Empirical Evidence. Journal of Business Ethics, 463-479. https://doi.org/10.1007/s10551-012-1272-Z

Handajani, L. S. (2014). Does board diversity matter on corporate social disclosure? An Indonesian evidence. Journal of Economics and Sustainable Development, 5(9), 8-16.

Harisson, D. A. (2007). What's the difference? Diversity constructs as separation, variety or disparity in organizations. Academy of Management Review, 32, 1199-1228. https://doi.org/10.5465/amr.2007.26586096

Harjoto, M. L. (2015). Board Diversity and Corporate Social Responsiblity. Journal Business Ethics, (132), $641-660$. https://doi.org/10.1007/s10551-014-2343-0

Hellsten, S. \&. (2006). Are 'Ethical' or 'Socially Responsible' Investments Socially Responsible?. Journal of Business Ethics, 66, 393-406. https://doi.org/10.1007/s10551-006-0001-X

Hill, N., \& Maroun, W. (2015). Assessing the Potential Impact of the Marikana Incident on South African Mining Companies: An Event Method Study. South African Journal of Economic and Management Science, 18(4), 586-607. https://doi.org/10.4102/sajems.v18i4.1345

Ho, S. S. (2001). A study of relationships between corporate governance structures and the extend of voluntary disclosure. Journal of International Accounting, Auditing and Taxation, 10(2), 139-156. https://doi.org/10.1016/S1061-9518(01)00041-6

Indarawati, T. R. (2016, June). The Impact of Environmental, Social and Governance Practices (ESG) on Economic Performance: Evidence from ESG Score. International Journal of Trade, Economics and Finance, 7(3), 67-74. https://doi.org/10.18178/ijtef.2016.7.3.501

Ismail, I. R. (2016). Sustainable development issues \& challenges associate in Malaysia.

John, C., \& Cruden, S. O. (2016). The Deepwater Horizon Oil Spill Litigation: Proof of Concept for the Manual for 
Complext Litigation and the 2015 Amendments to the Federal Rules of Civil Procedure. Michigan Journal of Environmental \& Administrative Law, 6(1), 65-149.

Klassen, R. D. (1996). The Impact of Environmental Management on Firm Performance. Management Science, 42(8), 1199-1214. https://doi.org/10.1287/mnsc.42.8.1199

Li, Y. (2010, October 10). The Case Analysis of the Scandal of Enron. International Journal of Business and Management, 5(10), 37-41. https://doi.org/10.5539/ijbm.v5n10p37

Lim, S. M. (2007). The association between board composition and different types of voluntary disclosure. European Accounting, 16(3), 555-583. https://doi.org/10.1080/09638180701507155

Luc Renneboog, J. T. (2008). The Price of Ethics and Stakeholder Governance: The Performance of Socially Mutual Funds. Journal of Corporate Finance, 302-322. https://doi.org/10.1016/j.jcorpfin.2008.03.009

Mac Donald, M. (2003). Review of Corporate Sustainability Reporting.

Malaysia, B. (2018). Main Market Listing Requirement. Kuala Lumpur: October.

Malaysia, D. O. (2017). Selected Agricultural Indicator, Malaysia. Putrajaya: Department of Statistics Malaysia.

Maroun, W. (2018). Evaluating the Temporal Dimension of Legitimisation Strategies: Evidence From Non-Financial Reporting in Response to a Social Crisis. Qualitative Research in Accounting \& Management, 282-312. https://doi.org/10.1108/QRAM-01-2017-0001

McClave, J. B. (2008). Statistics for business and economidwv (8th ed.). New Jerseu: Prentice Hall International.

Melewar, T. (2010). Determinants of the corporate indentity construct: a review of literature. Journal of Marketing Communications, 195-220. https://doi.org/10.1080/1352726032000119161

Montiel, I. (2008). Corporate Social Responsiblity and Corporate Sustainability: Separate Pasts, Common Future. Organization \& Enviroment, 21(3), 245-269. https://doi.org/10.1177/1086026608321329

Moon, J. (2007, September). The cotribution of corporate social responsibility to sustainable development. Sustainable Development, 15(5), 296-306. https://doi.org/10.1002/sd.346

Noranida, M., (2014). Malaysia's efforts toward achieving a sustainable development: Issues, challenges and $\begin{array}{lllll}\text { prospect. Procedia } & -S o c i a l & \text { and }\end{array}$ https://doi.org/10.1016/j.sbspro.2014.02.107

Norsyahida, M., \& Sulaiman, M. (2012). Environmental Reporting Practices of Malaysian Government Linked Companies (GLCs). International Journal of Economics and Management, 6(2), 241-277.

OECD. (2017). Investment governance and the integration of environmental, social and governance factors. OECD.

Oikonomou, I. B. (2012). The impact of corporate social performance on financial risk and utility: A longitidinal analysis. Financial Management, 41(2), 483-515. https://doi.org/10.1111/j.1755-053X.2012.01190.x

Oluwaseun, G. O., \& Boboye, L. A. (2017). Randomness of stock return in Nigerian banking sector. Asian Journal of Economics and Empirical Research, 4(2), 99-105. https://doi.org/10.20448/journal.501.2017.42.99.105

Omodero, C. O., \& Ogbonnaya, A. K. (2018). Corporate tax and profitability of deposit money banks in Nigeria. Journal of Accounting, Business and Finance Research, 3(2), 47-55. https://doi.org/10.20448/2002.32.47.55

Onyinye, I., Orji, A., Jonathan, E., \& Emmanuel, O. (2018). Disaggregated Foreign Capital Inflows and Economic Growth in a Developing Economy: Empirical Evidence from Nigeria. Journal of Empirical Studies, 5(1), 1-11. https://doi.org/10.18488/journal.66.2018.51.1.11

Orji, A., Ogbuabor, J. E., \& Anthony-Orji, O. I. (2018). Macroeconomic Indicators and Capital Formation Growth in Nigeria: A New Evidence. Journal of Social Economics Research, 5(2), 39-50. https://doi.org/10.18488/journal.35.2018.52.39.50

Orji, A., Ogbuabor, J. E., Okon, A. N., \& Anthony-Orji, O. I. (2018). Electronic Banking Innovations and Selected Banks Performance in Nigeria. The Economics and Finance Letters, 5(2), 46-57. https://doi.org/10.18488/journal.29.2018.52.46.57

Osabohien, R., Osuma, G., Ndigwe, C., \& Ozordi, E. (2018). Social Protection and Agricultural Production in Ecowas: The Youth Unemployment Question. Journal of Social Economics Research, 5(2), 51-62. https://doi.org/10.18488/journal.35.2018.52.51.62 
Parkinson, J. (1993). Corporate Power and Responsbilities: Issues in the Theory of Company Law. Oxford: Oxford University Press.

Peiris, D. \& Evans, J. (2010). The relationship between environmental social governance factors and US stock performance. The Journal of Investing, 19(3), 104-112. https://doi.org/10.3905/joi.2010.19.3.104

Peiro-Signes, A. D.-O.-J.-V. (2013). Influence of the environmental, social and corporate governance ratings on the economic performance of companies: an overview. International Journal of Environmental Research, 7, 105-112.

Pfeffer, J., \& Salancik, G. (1978). The External Control of Organization: A Resource Dependence Perspective, pp. $39-61$.

Porter, M. E. (1985). Competitive Advantage: Creating and Sustaining Superior Performance. New York: The Free Press.

Post, C. R. (2011). Green governance: Board of directors' composition and environmental corporate social responsibility. Business \& Society, 50(1), 189-223. https://doi.org/10.1177/0007650310394642

Preub, B. (2017). Nordic Management and Sustainable Business. Journal of Business and Financial Accountring, $6(2), 1-9$.

Qian, L. A. (2016). Environmental, Social and Governance and the Efficiency of Government-linked Companies in Malaysia. Institutions and Economies, 9(2), 55-74.

R, U. S. (2010). Research methods for business: A skill buidling apporach (5th ed.). West Sussex, UK: John Wiley $\&$ Sons Ltd.

Rao, K., \& Tilt, C. (2016). Board diversity and CSR reporting: an Australian study. Meditary Accounting Research, 24(2), 182-210. https://doi.org/10.1108/MEDAR-08-2015-0052

Renneboog, L. H. (2008). The price of ethics and stakeholder governance: The performance of socially responsible mutual funds. Journal of Corporate Finance, 14(3), 302-322. https://doi.org/10.1016/j.jcorpfin.2008.03.009

Rhodes, M. J. (2010). Information Asymmentry and Socially Responsible Investment. Journal of Business Ethics, 145-150. https://doi.org/10.1007/s10551-009-0343-2

Richardson, B. J. (2009). Keeping ethical investment ethical: Regulatory issues for investing for sustainability. Journal of Business Ethics, 87(4), 555-572. https://doi.org/10.1007/s10551-008-9958-y

Roselle, P. (2016). The evolution of integrating ESG analysis into wealth management decision. Journal of Applied Corporate Finance, 28, 75-79.

Ruhaya, A. F. (2016). Environmental, Social and Governance (ESG) Disclosure and its Effect on Firm's Performance: A Comparative Study. International Journal of Economics and Management, 355-375.

Securities Commission. (2017). Malaysia Code on Corporate Governance. Kuala Lumpur: Securities Commission Malaysia.

Securities Commission. (2018). Corporate Governance Strategic Priorities 2017 - 2020. Kuala Lumpur: Securities Commission Malaysia.

Smith, D., Rupp, W., \& Motley, D. (2013). Corporate reputation as strategic competitive advantage of manufacturing and service-based firm: Multi-industry case study. International Journal of Services and Operations Management, 14(2), 131-156. https://doi.org/10.1504/IJSOM.2013.051826

Sontaite-Petkeviciene, M. (2013). CSR Reasons, Practices and Impat to Corporate Reputation. Procedia - Social and Behavioural Sciences, 503-508. https://doi.org/10.1016/j.sbspro.2015.11.441

Sparkes, R. (2001, July). Ethical investment: Whose ethics, which investment?. Business Ethics, 10(3), 194-205. https://doi.org/10.1111/1467-8608.00233

Sroka, R. (2013). ESG transparency as competitive advantage for listed companies. Warszaw: Polish Association of Listed Companies (SEG).

Terjesen, S. S. (2009). Women Directos and Corporate Boards: A Review and Research Agenda. Corporate Governance: An internal Review, 17(3), 320-337. https://doi.org/10.1111/j.1467-8683.2009.00742.x

Thomson Reuters. (2018). Thomson Reuters ESG Scores. New York: Thomson Reuters. 
Tilt, K. R. (2016). Board Composition and Corporate Social Responsibility: The Role of Diversity, Gender, Strategy and Decision Making. Journal of Business Ethics, 327-347. https://doi.org/10.1007/s10551-015-2613-5

Vafaei, A. A. (2015). Board Diversity and Financial Performance in the Top 500 Australian Firms. Australian Accounting Review, 25(4), 413-427. https://doi.org/10.1111/auar.12068

Venturelli, A. C. (2017). How can CSR indentity be evaluated? A pilot study using a Fuzzy Expert System. Journal of Cleaner Production, 141, 1000-1010. https://doi.org/10.1016/j.jclepro.2016.09.172

Waddock, S., \& Graves, S. (1997). Finding the link between stakeholder relations and quality of management. Journal of Investing, 6(4). https://doi.org/10.3905/joi.1997.408435

Waddock, S. A. (1997, April). The Corporate Social Performance - Financial Performance Link. Strategic $\begin{array}{lll}\text { Management } & \text { Journal, } & \text { 303-319), }\end{array}$ https://doi.org/10.1002/(SICI)1097-0266(199704)18:4<303::AID-SMJ869>3.3.CO;2-7

Wang, M.-C. (2017). The relationship between firm characteristics and the disclosure of sustainability reporting. Sustainability, 9(624), 1-14. https://doi.org/10.3390/su9040624

\section{Note}

Note 1. ACE Market - stands for 'Access, Certainty, Efficiency' is a new name for the formally known MESDAQ (Malaysian Exchange of Securities Dealing and Automated Quotation) market. 